\title{
Exploring the Use of Social Media on Teaching and Learning Science from Teachers and Students Viewpoint
}

\author{
Raziyeh Rezaei ${ }^{1}$, Fatemeh Zarei ${ }^{2, *}$ Hadi Tehrani ${ }^{3}$ \\ ${ }^{1}$ MSc Student, Department of Health Education and Health Promotion, School of Public Health \\ Zanjan University of Medical Sciences, Zanjan Iran \\ ${ }^{2}$ Assisstant Professor, Department of Health Education and Health Promotion. Faculty of Medical \\ Sciences, Tarbiat Modares University, Tehran, Iran \\ 3 Assistant Professor of Health Education and Health Promotion, Social Determinants of Health \\ Research Center, Mashhad University of Medical Sciences, Mashhad, Iran \\ * Corresponding author: Fatemeh Zarei, Assisstant Professor, Department of Health Education and \\ Health Promotion. Faculty of Medical Sciences, Tarbiat Modares University, Tehran, Iran. E-mail: \\ f.zarei@modares.ac.ir
}

Received: 03 Oct 2017

Accepted: $19 \operatorname{Dec} 2017$

\begin{abstract}
Introduction: According to scientific evidence, a social media in education and research for postgraduate students seems necessary. Since college students and faculty members are considered as the online platforms clients, the current study aimed at qualitatively analyzing the viewpoints of students and Universities professors toward the application of the online social media to learning and education sciences in University.

Methods: The current study was conducted using the qualitative content analysis methods. The participants were selected using the purposive sampling method $(n=24)$. Data were collected through semi-structured deep interviews, recorded on audiotapes, transcribed, and then, analyzed. MaxQdata software version 10, according to the qualitative content analysis developed by Granheim and Lundman, was used for data analysis.

Results: Data analysis led to the extraction of 279 codes, 15 sub-codes, six Sub-Categories, and Two main categories. The main categories included the perceived advantages of social networks in education and learning process (Four Sub-Categories, perceived disadvantages of social networks in education and learning process (Two Sub-Categories).

Conclusions: The use of virtual social networks in both education and learning process from the viewpoint of the teacher and student as the beneficiaries of this area is acceptable. Enriched webbased learning, despite the perceived obstacles and challenges, is suitable to facilitate, accelerate, and create creativity in the educational process.
\end{abstract}

Keywords: Eduation, Learning, Virtual Social Media; Qualitative Study

(c) 2018 Iranian Nursing Scientific Association (INA) 


\title{
واكاوى بكار تيرى شبكهاى اجتماعى مجازى در يادكيرى و آموزش از منظر استادان و دانشجويان شبكههاى اجتماعى مجازى درى آموزئش
}

\author{
راضيه رضايى '، فاطمه زارعى r.** هادى طهرانى
}

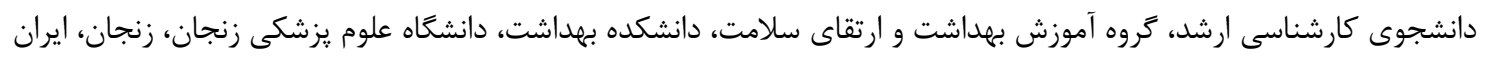

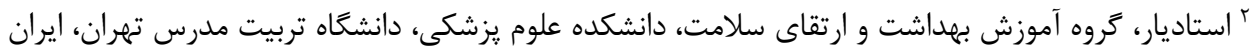

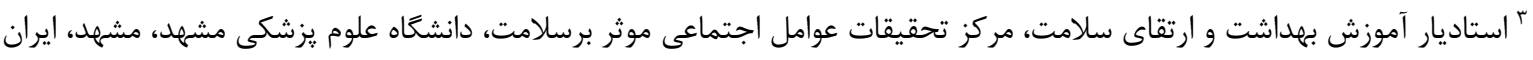

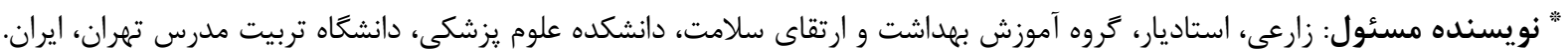

ايميل: f.zarei@modares.ac.ir

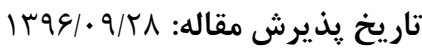

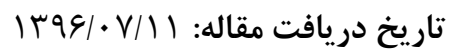

مقدمه: به يشتوانه شواهد علمى بهينه سازى نظام آموزش و يزوهش در بستر شبكههاى اجتماعى مجازى در بين دانشجويان تحصيلات

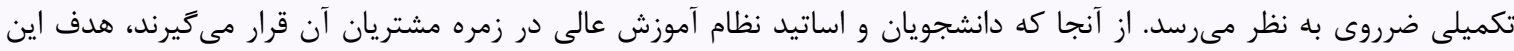

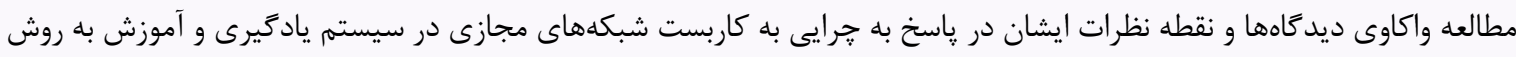
شناسى كيفى بود.

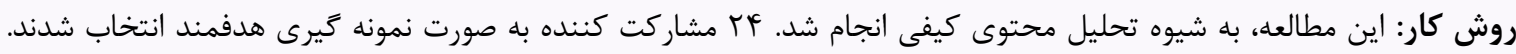

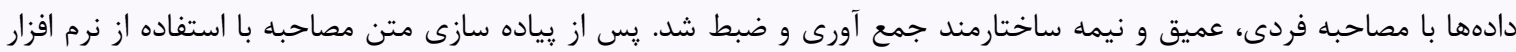

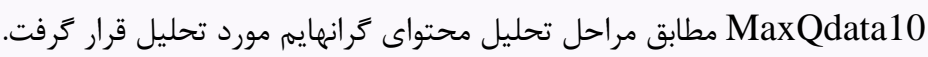

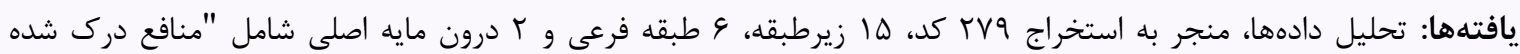

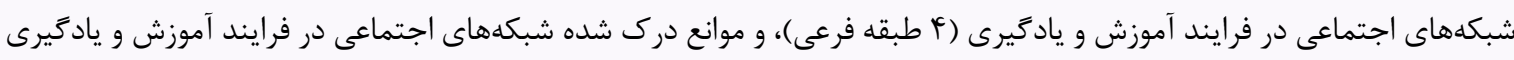
(r طبقه فرعى)" كرديد.

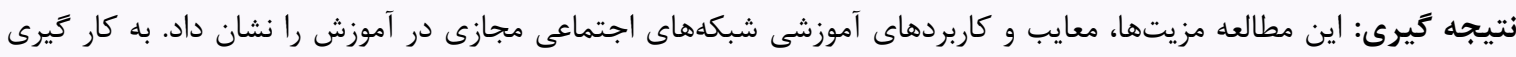

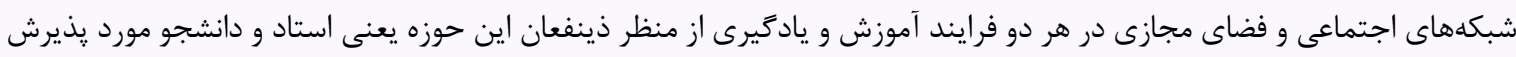

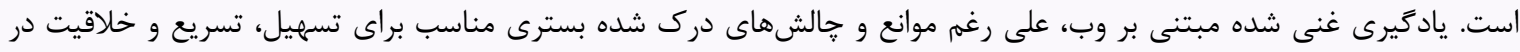
فرايند آموزشى است. وازَّان كليدى: يادَيرى، آموزش، شبكههاى اجتماعى، مطالعه كيفى

مهارتهاى تحصيلى آنها، تأثير مستقيم و غيرمستقيم داشته است (Iا).

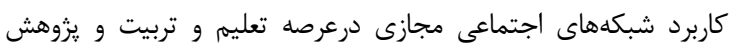

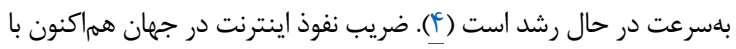

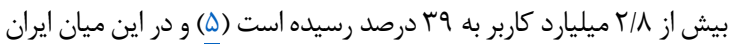

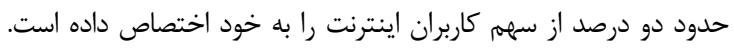

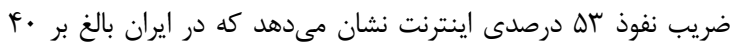

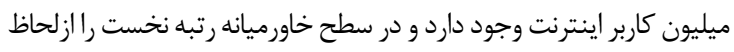

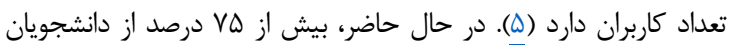

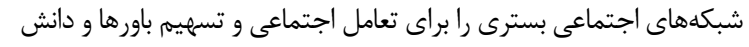

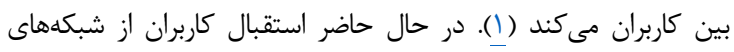

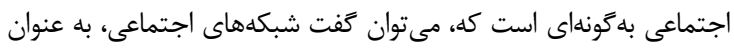

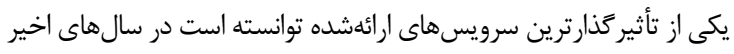

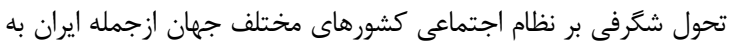

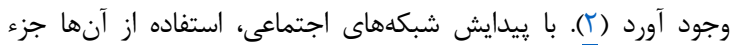

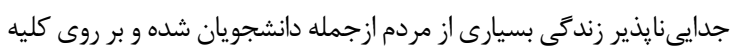

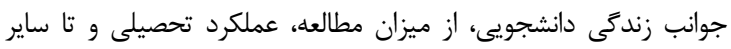


در زمره آن كاربران قرار مى يريرند، برآن شديم تا با روششناسى كيفى به

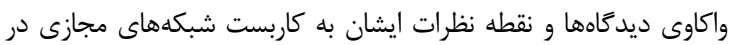

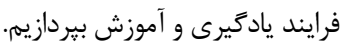

\section{روش كار}

اين يثوهش با استفاده از روش تحليل محتواى كيفى انجام شد. تحليل

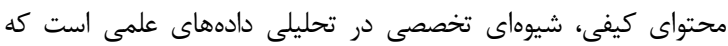

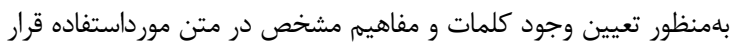

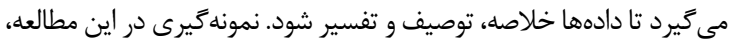

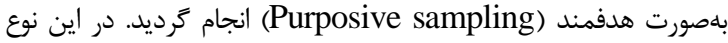

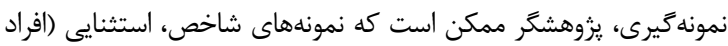

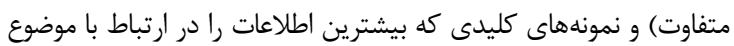

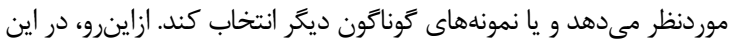

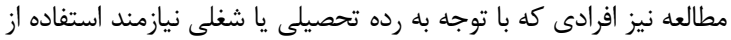

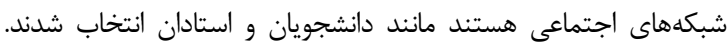

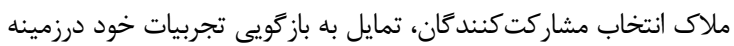

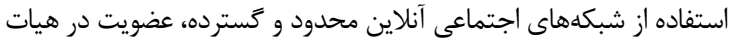

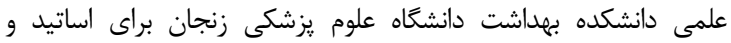

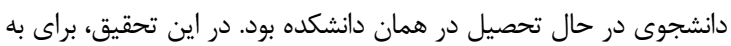

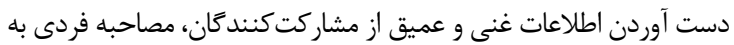

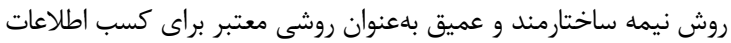

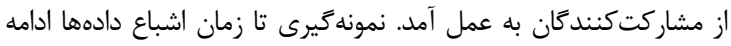

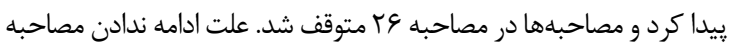

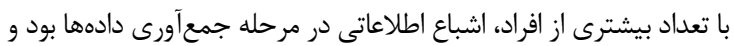

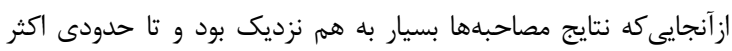

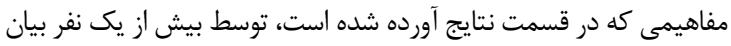

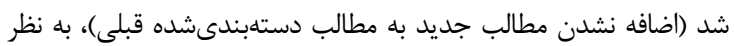

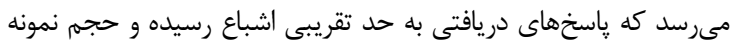

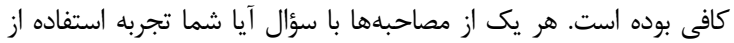

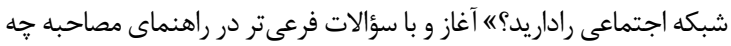

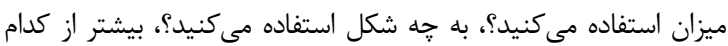
شبكها استفاده مي كنيد؟، ادامه يافت.

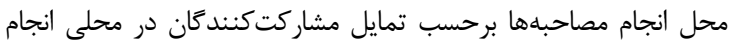

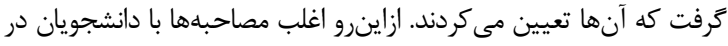

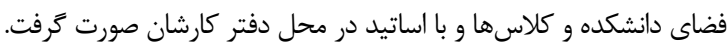

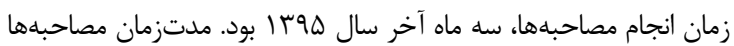

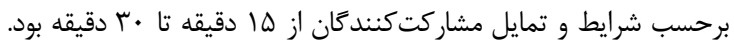

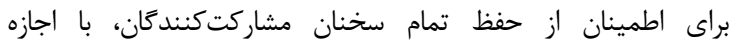

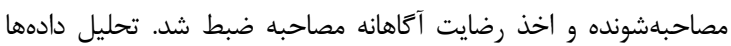

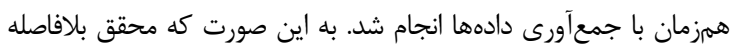

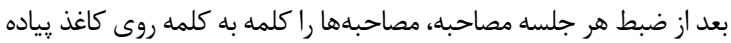

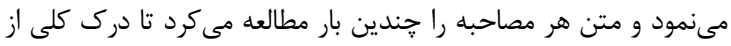

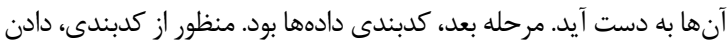

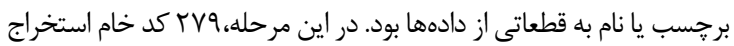

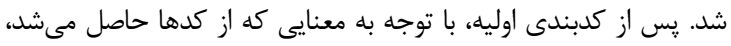

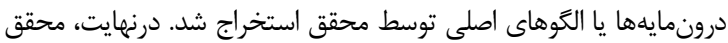

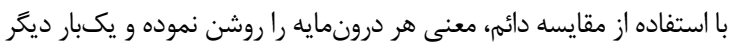

كاربران فعال شبكه اجتماعى همجيون فيس بوك هستند و اين شبكههاى

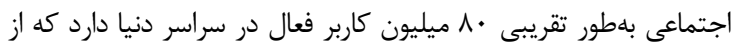

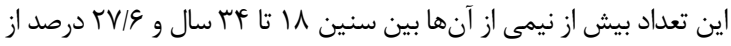

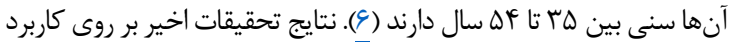

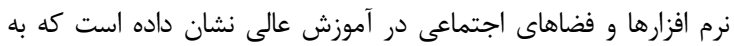

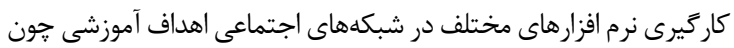

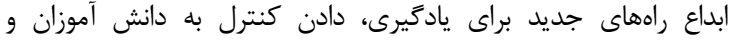

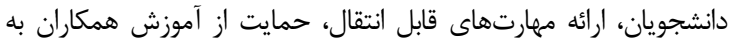

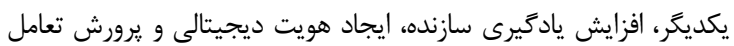

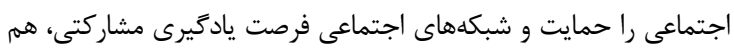

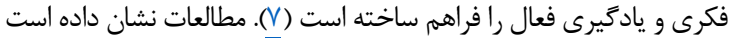

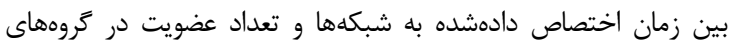

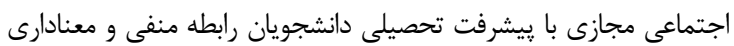
وجود داشت. بلطورى كه بيشرفت تحصيلى دانشجويانى كه از از شبكهدهاى

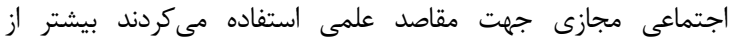

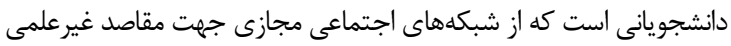

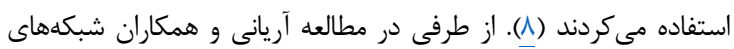

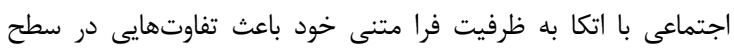

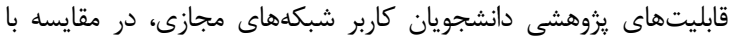

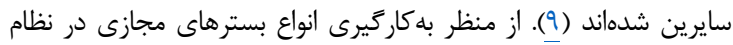

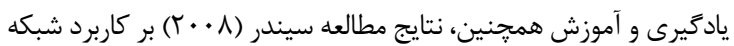

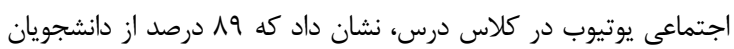

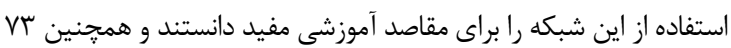

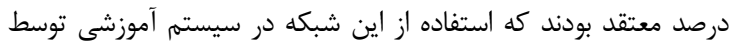

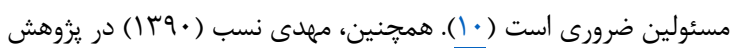

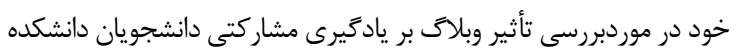

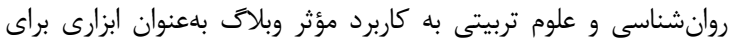

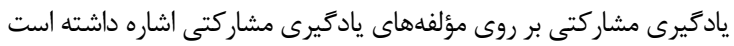

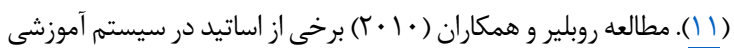

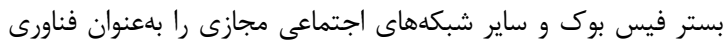

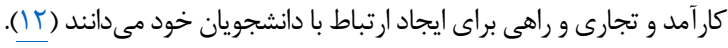

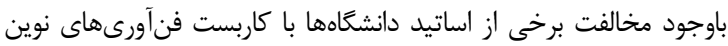

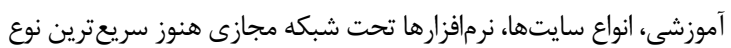

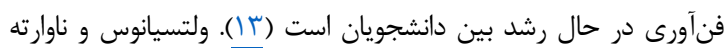

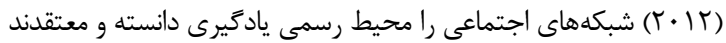

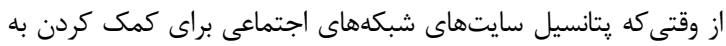

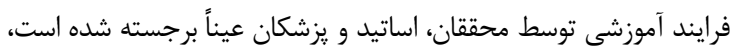

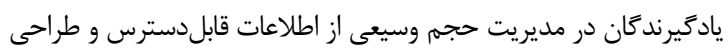

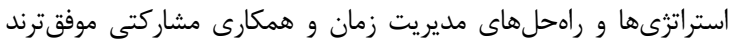

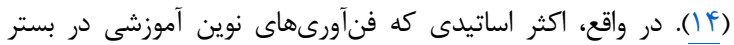

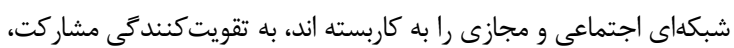

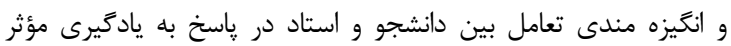

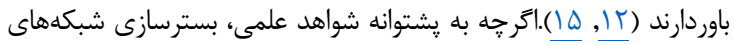

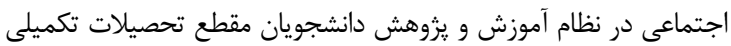

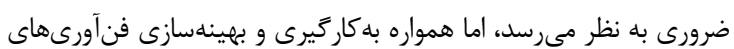

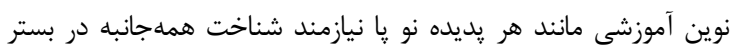
فرهنكى جامعه هدف است. ازآنجاكه دانشجويان و اساتيد نظام آموزش عالى ندانى 
شد تا كدها و دستابندىها را بررسى و مورد تائيد قرار دهند. قابليت انتقال

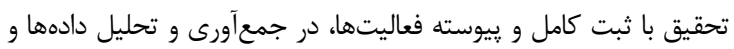

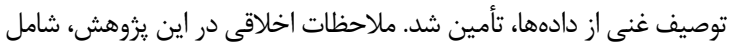

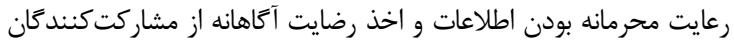

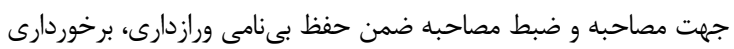

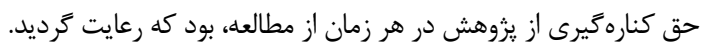

\section{يافتهها}

مشخصات مشاركتكنندًان تحقيق از قبيل رشته تحصيلى، مقطع

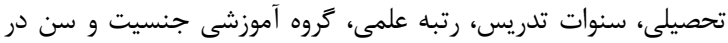
جدول إنشان دادهده است.
در مورد دستدبندى اطلاعات در مراحل قبل تصميمكيرى نمود. تمامى

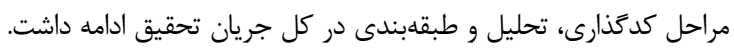

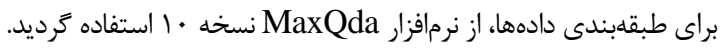

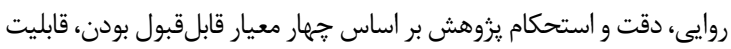

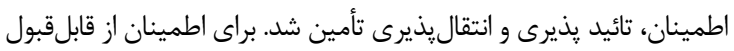

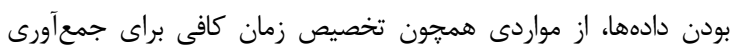

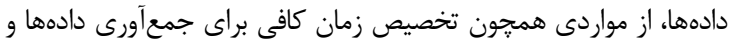

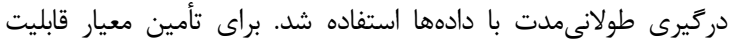

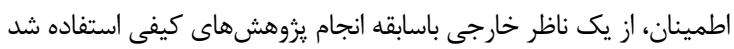

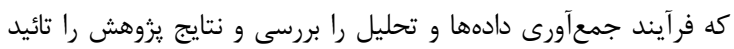

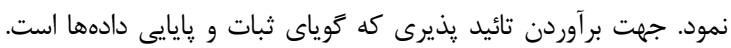
علاوه بر اين رعايت بى طرفى محققان، از نظرات تكميلى همكاران استفاده

جدول ا: مشخصات دموكرافيك مشاركت كنندگان

\begin{tabular}{|c|c|}
\hline \multirow[t]{2}{*}{ تعداد/درصد } & 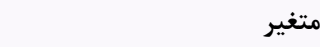 \\
\hline & اساتيد \\
\hline r بنفر •r درصد & مربى \\
\hline ه نفر • له درصد & استاديار \\
\hline r انفر •r درصد & دانشيار \\
\hline \multirow[t]{2}{*}{$\cdot$} & 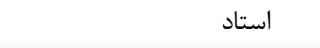 \\
\hline & سنوات تدريس \\
\hline r انفر •r درصد & زير ه سال \\
\hline r ا نفر •r درصد & 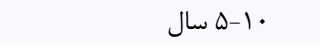 \\
\hline \multirow[t]{2}{*}{ ونفر •4 درصد } & بالاى • ا سال \\
\hline & كروه آموزشى \\
\hline ا نفر ·ا درصد & بهداشت عمومى \\
\hline 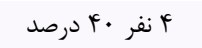 & بهداشت محيط \\
\hline ا نفر •ا دردصد & كاردرمانى \\
\hline r r انفر درصد & بهداشت حرفهاى \\
\hline \multirow[t]{2}{*}{ r انفر •r درصد } & آموزش بهداشت \\
\hline & سن ميانگين و انحر اف معيار \\
\hline$\cdot$ & زير ·r سال \\
\hline 1 & 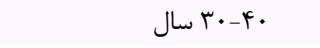 \\
\hline$\Gamma r / / \varphi \pm r / \Lambda \Delta$ & 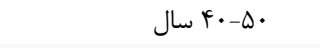 \\
\hline \multirow[t]{3}{*}{$\Delta r / r r \pm r / \Delta \mid \varphi$} & بالاى •0 سال \\
\hline & دانشجو \\
\hline & رشته تحصيلى \\
\hline أ نفر YN/DV درصد & بهداشت مواد غذايى \\
\hline F نفر Y T د درصد & بهداشت محيط \\
\hline \multirow[t]{2}{*}{ צنفر AT/AD درصد } & بهداشت حرفهاى \\
\hline & جنسيت \\
\hline 9 نفر 19/א درصد & 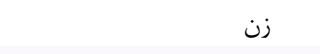 \\
\hline \multirow[t]{2}{*}{ ه نفر آها درصد } & 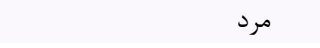 \\
\hline & سن (ميانَين و انحر اف معيار) \\
\hline$\cdot$ & زير •r سال \\
\hline$r \varepsilon / \Lambda \Lambda \pm r / r \mid \Delta$ & $r F-r$. \\
\hline rG/VD \pm r/AGT & 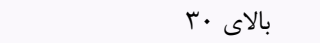 \\
\hline
\end{tabular}




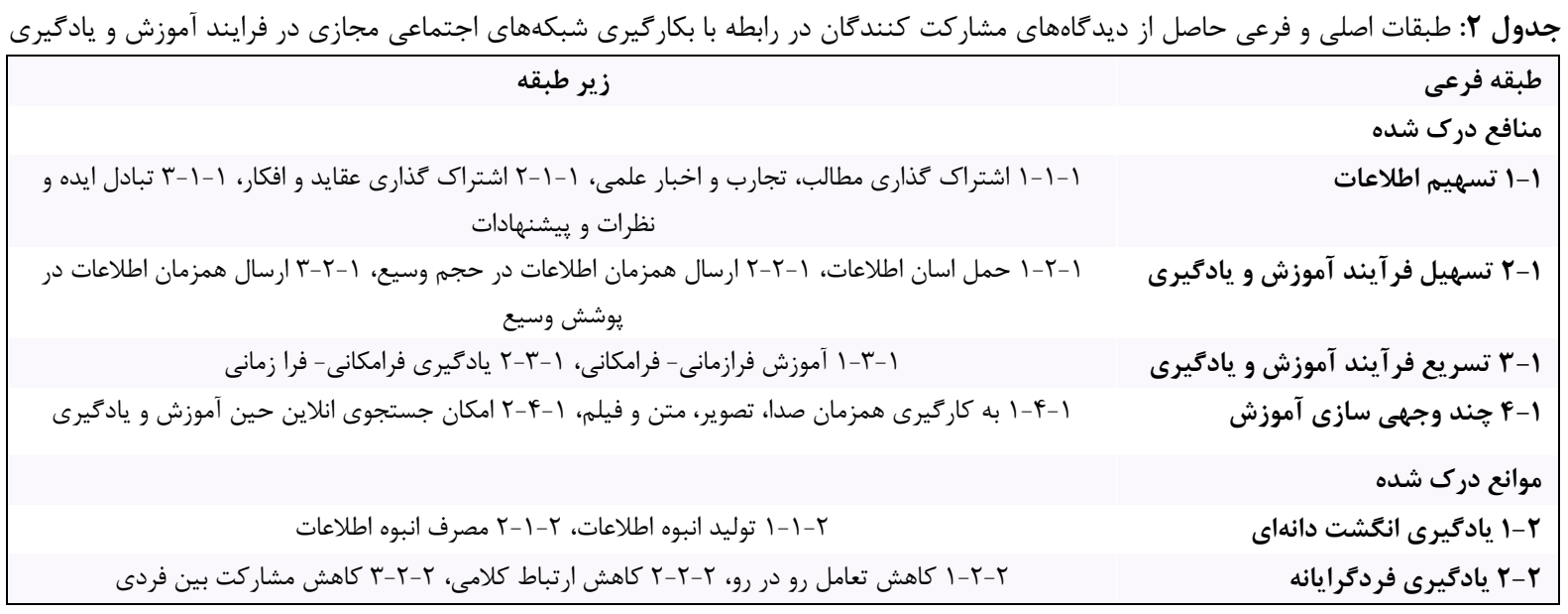

الآن يك سرى گروههايى داريم. تروههاى آموزشى مربوط به رشته

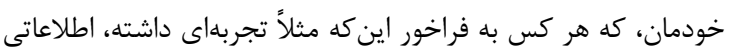

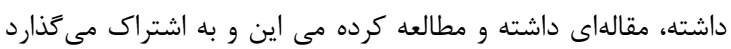

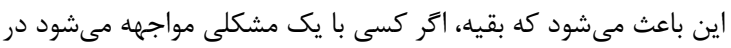

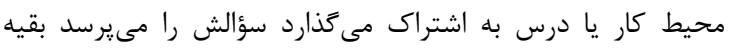

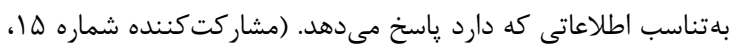
دانشجو، رشته كارشناسى ارشد بهداشت حرفهاى).

\section{|-1 -1 اشتراك كذارى عقايد و افكار}

درونمايه ديخرى كه يس از تحليل مصاحبهها از ديدكاه مشاركت كنندكان

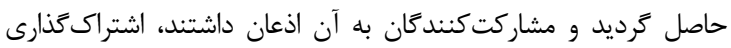

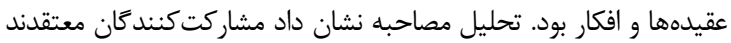

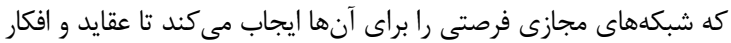

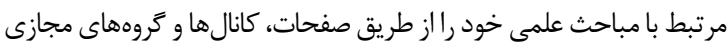

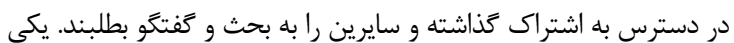

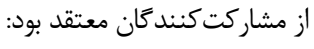

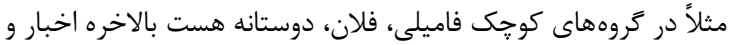

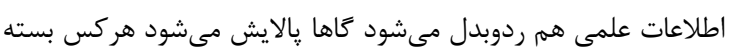
به تخصص خودش نظر مى دهد حون به رهر حال موضوعات در شبكه مهاى

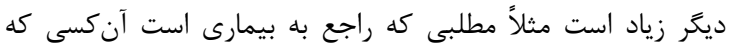

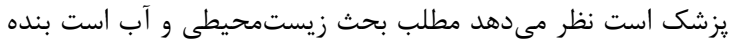

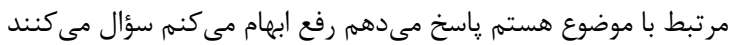

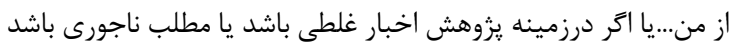

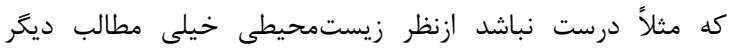

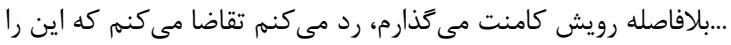

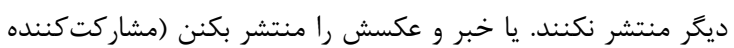

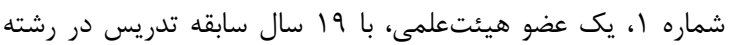

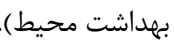

\section{1-1-r تبادل ايده و نظرات و ييشنههادات}

بر اساس اين درونمايه شبكههاى اجتماعى مجازى امكان تبادل و و

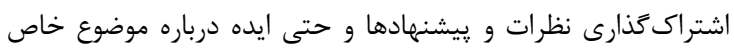

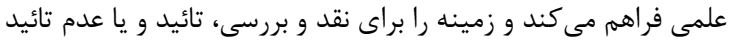

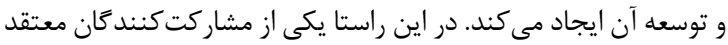

تحليل كفتههاى مشاركت كنندكان در رابطه با تبيين كاربرد شبكههاى

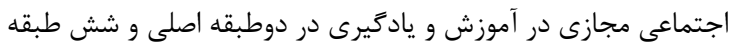

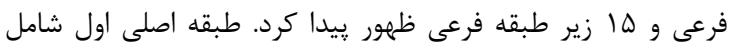

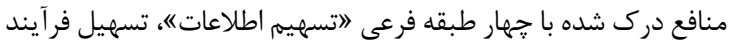

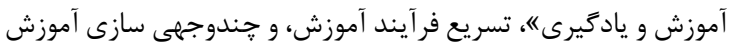

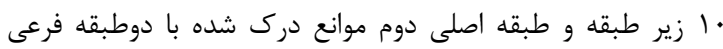

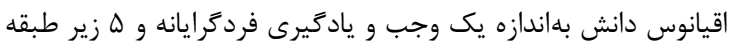

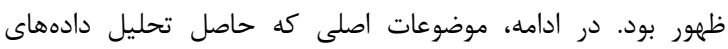

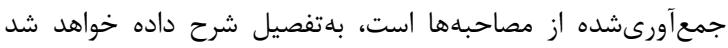

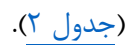

ا منافع درك شده

اين درون مايه از جهار طبقه فرعى " تسهيم اطلاعات،، تسهيل فرآيند

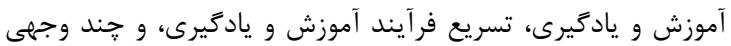

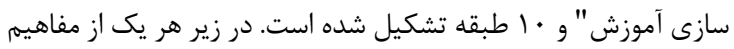
به تفصيل شرح داده شده است.

1-1 إتسهيم اطلاعات

اين طبقه حاصل تحليل كامل مصاحبهها بود و از ديدكاه

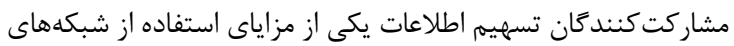

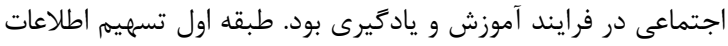

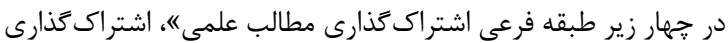

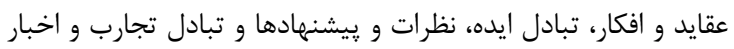

$$
\text { علمى طبقهبندى شد. }
$$

1-1-1 شتراك كذارى مطالب، تجارب و اخبار علمى مشاركت كنندكان اين مطالعه معتقد بودند استفاده از شبكههاى مجازى

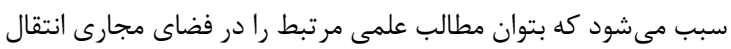

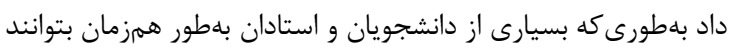

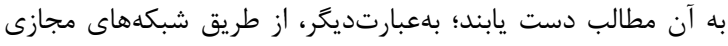

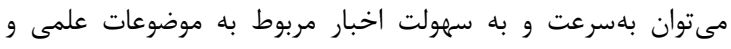

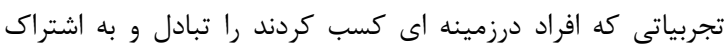

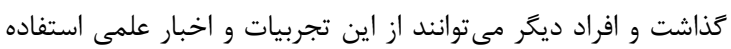

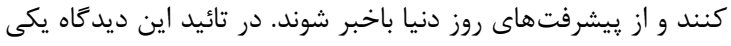

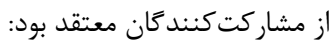


يكزمان و در يك سطح وسيع و گسترده است. بهعبارتديخر تعداد

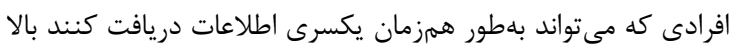

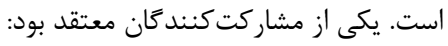

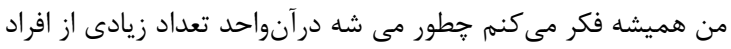

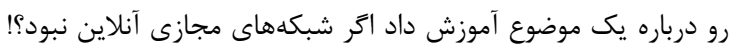

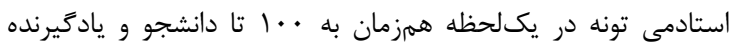

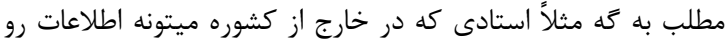

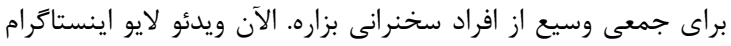

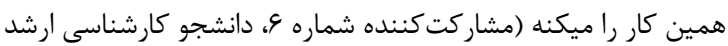
بهداشت مواد غذايى) (مئ)

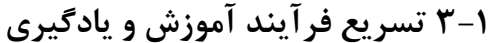

اين طبقه حاصل تحليل كامل مصاحبهها بود و مشاركت كنندًان

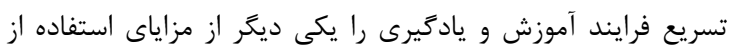

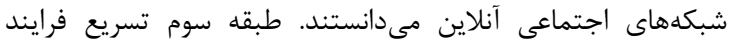
آموزش و يادكيرى" در دو زير طبقه فرعى اجنى برطرف ساختن

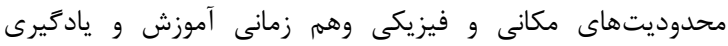
طبقلهبندى شد.

\section{ا-r-I آموزش فرازمانى - فرامكانى}

بر اساس تحليل مصاحبههاى يروهش استفاده از فضاهاى مجازى سبب

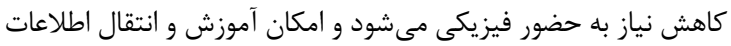

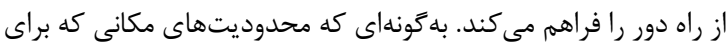

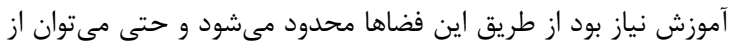
بين برد. يكى از مشاركت كنندكان معتقد بود:

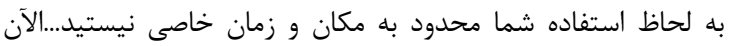
خيلىها اين در اين شبكههاى اجتماعى عضو هستند تلفنشان در دران

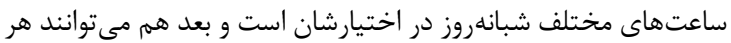

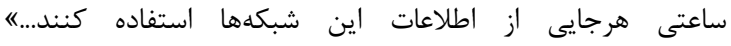

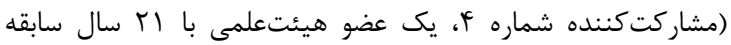

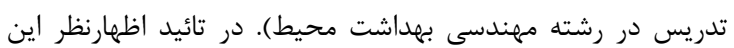

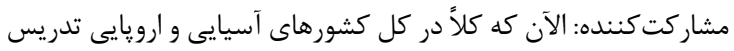

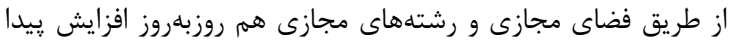

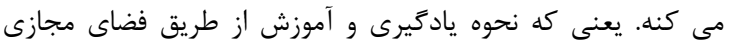

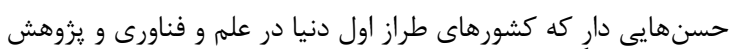
از آن استفاده مى كنن ماها هم بايد بيشتر استفاده كنيه. (مشاركت

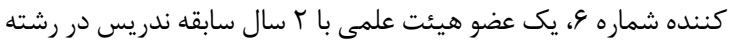

$$
\text { كار درمانى). }
$$

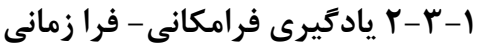

مشاركت كنندكان در اين مطالعه معتقد بودند كه شبكههاى اجتماعى

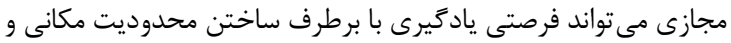

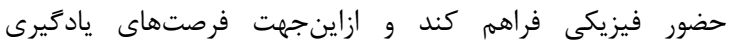

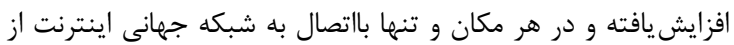

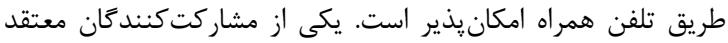

بزركترين مزيتش همين هست كه من مى تونم براحتى از فرصتهاى

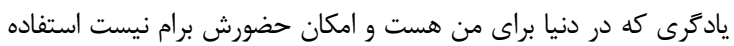

مثلاً خيلى وقتها شده من درباره يك كار تحقيقاتى ايدهاى به نظرم

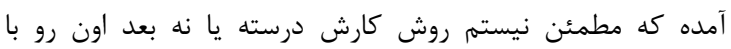

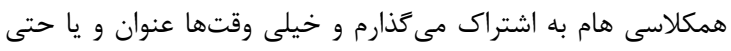

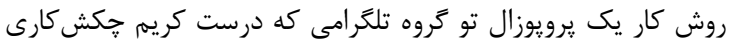

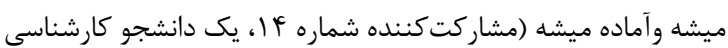
ارشد رشد آموزش بهداشت).

\section{I-1 T تسهيل فر آيند آموزش و يادَّيرى}

اين طبقه حاصل تحليل كامل مصاحبهها بود و مشاركت فنندگًان

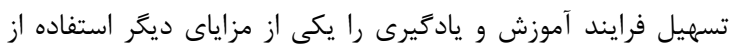

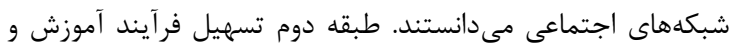

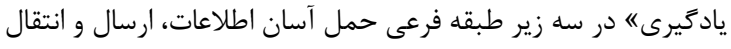

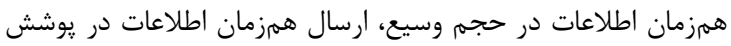
وسيع طبقهبندى شد.

1-r-1 حمل اسان اطلاعات

تحليل مصاحبه هاى يزوهش نشان داد كه استفاده از فضاهاى مجازى

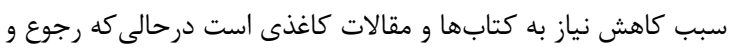

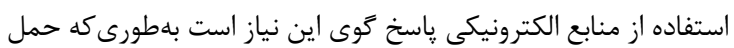

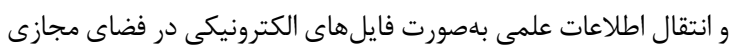

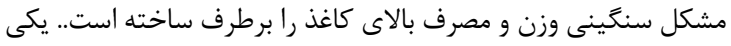

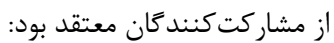

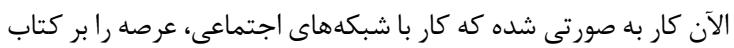

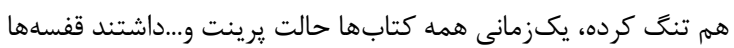

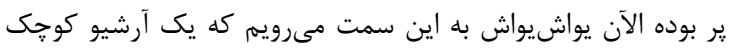

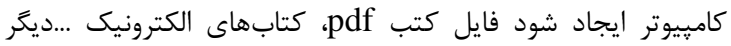

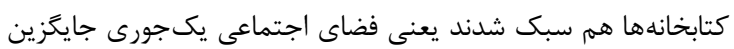

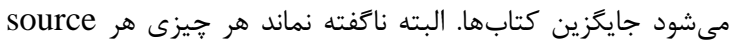

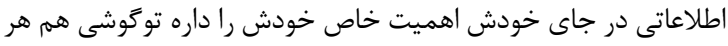

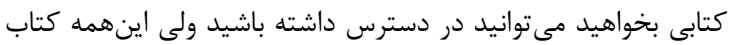

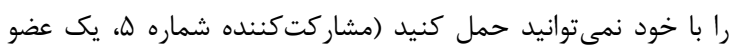

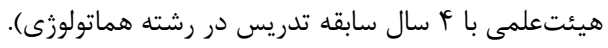

\section{| -r-r ارسال همزمان اطلاعات در حجم وسيع}

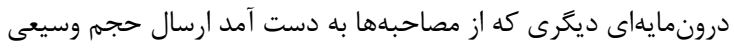

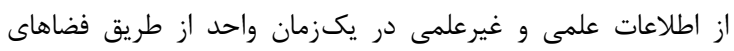

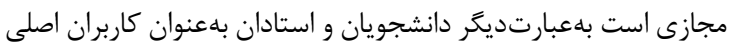

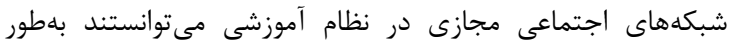

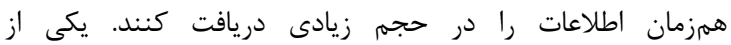
مشاركت كنند مان معتقد بود: مثلات

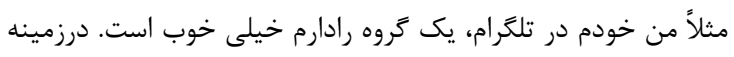

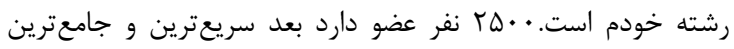

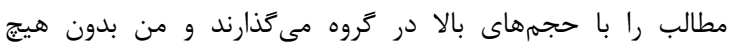

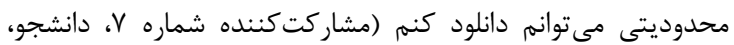

رشته كارشناسى ارشد رشته بهداشت حرفهاى).

\section{1-r-r-r ارسال همزمان اطلاعات در يوشش وسيع رسيع}

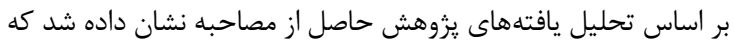

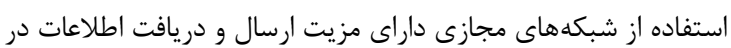


r-1 يادَيرى انَشت دانهاى (اقيانوس دانش به عمق يك

وجب)

بر اساس تحليل ديدكاه مشاركت كنندكان يكى از معايب استفاده از

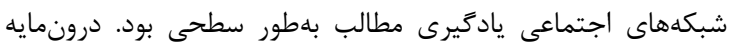

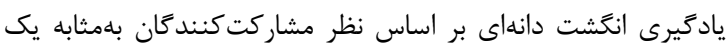

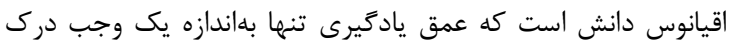

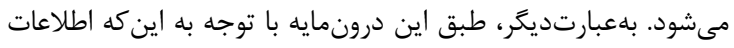

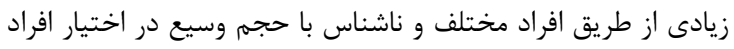

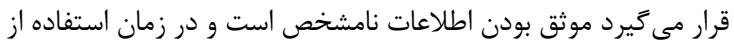

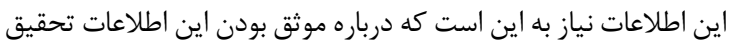

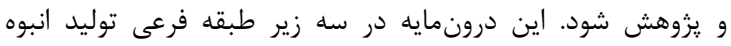

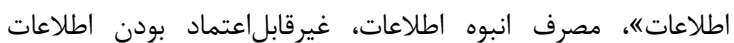

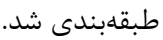

\section{r-1-1 توليد انبوه اطلاعات}

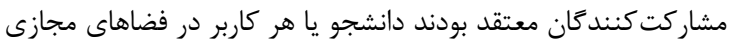

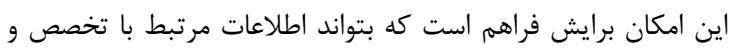

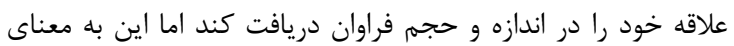

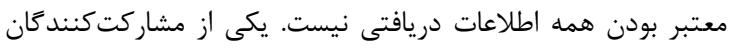
معتقد بود: خب واقعيت اين هست كه خيلى دسترسى به اطلاعات زياده اونقدر

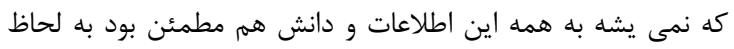

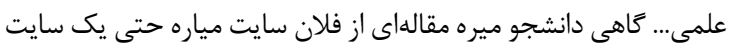

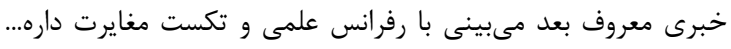

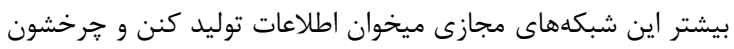

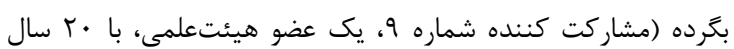

سابقه تدريس در رشته بهداشت عمومى).

r-1-r مصرف انبوه اطلاعات

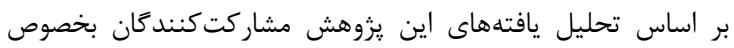

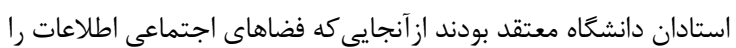

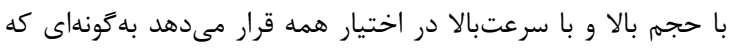

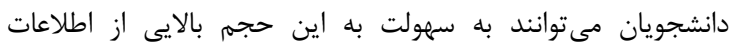

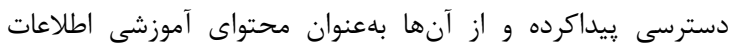

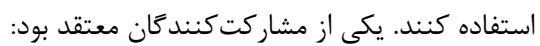

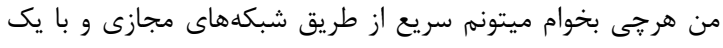

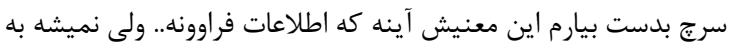

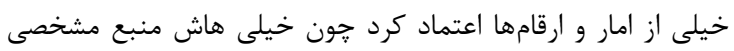

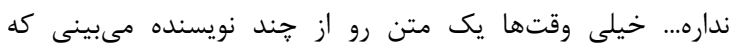
هستش...) (مشاركت كننده شماره 19 دانشجوى كارشناسى ارشد

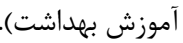
به اصطلاح قابل وثوق نيستند زياد بهشان نمى توان اعتماد كرد بعضى ها

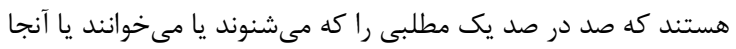

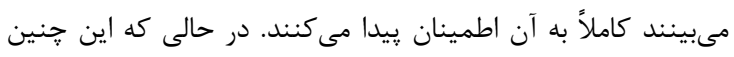

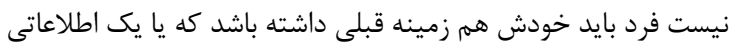

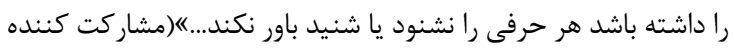

كنم ... خودم بارها در كورس هاى انلاين دانشكاههاى برتر دنيا ثبت نام

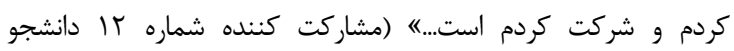

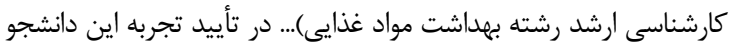

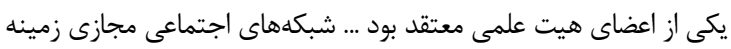

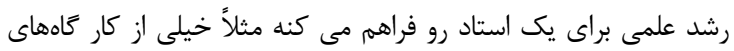

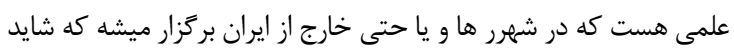

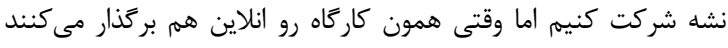

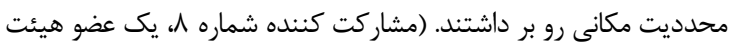
علمى با 9 سال سابقه تدريس در بهداشت حرفهائ).

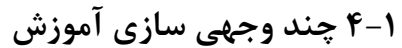

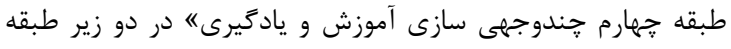

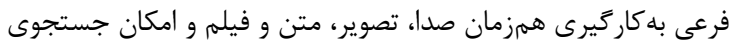

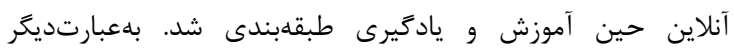

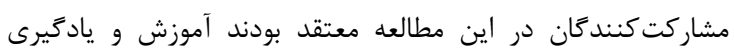

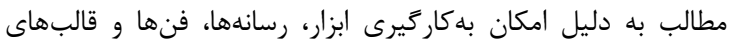

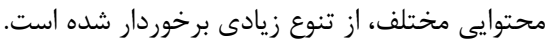

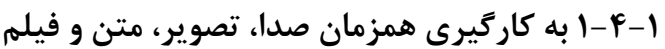

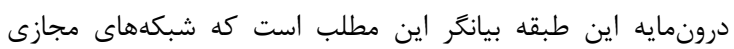

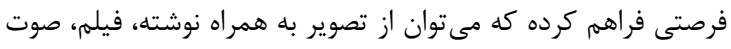

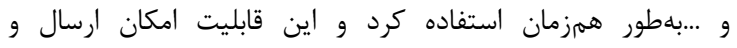

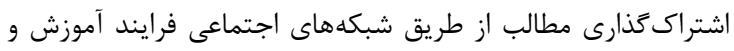

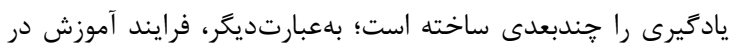

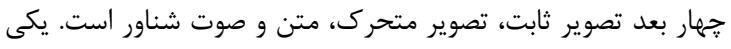

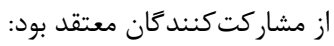

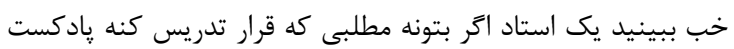

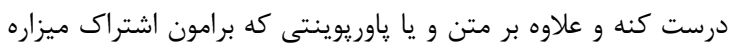

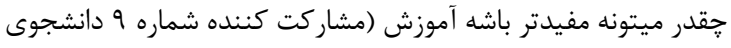
كارشناسى ارشد بهداشت محيط).

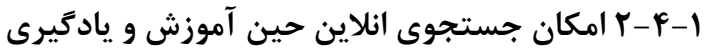

بر اساس اين درونمايه شبكههاى اجتماعى مى توانند امكان جستجوى

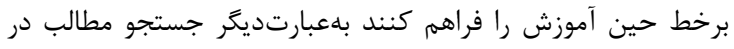

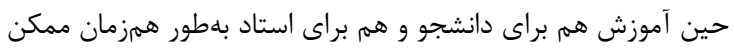

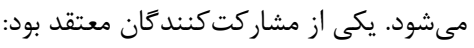

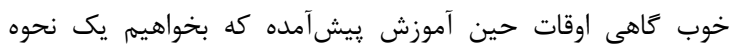

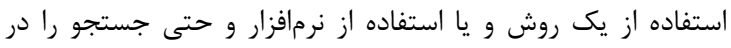

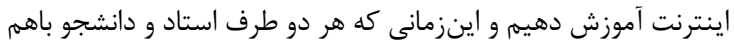

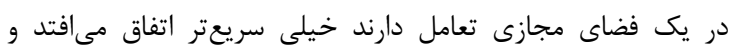

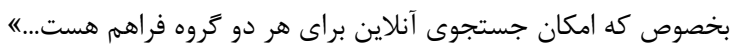

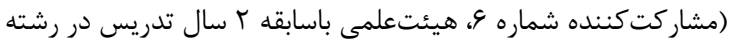

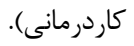

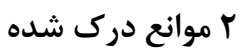

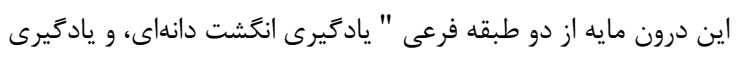

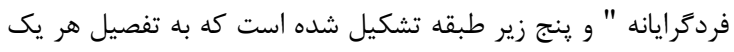
از اين مفاهيم شرح داده شده است. 
خواستيم مىرويم سرج مى كنيم و درمياوريم جه لزومى دارد كه من دو

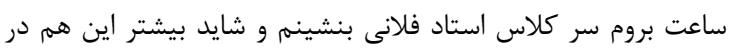

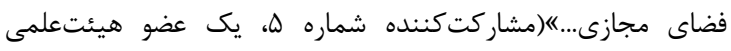
باسابقه F سال تدريس در، رشته: هماتولوزى).

هدف از انجام مطالعه حاضر، تبيين ديدكاه دانشجويان تحصيلات

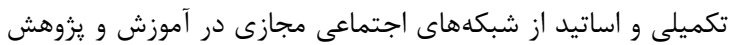

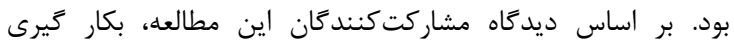

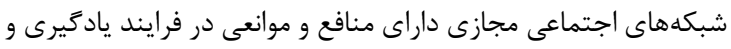

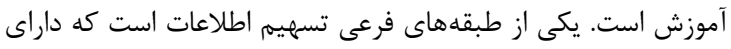

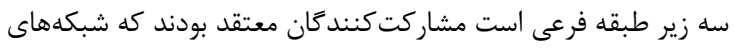

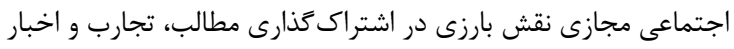

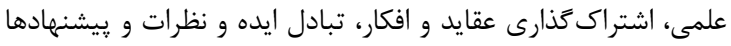

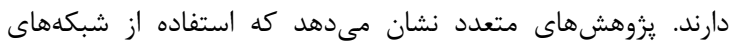

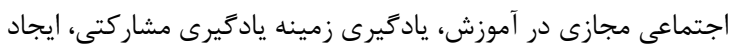

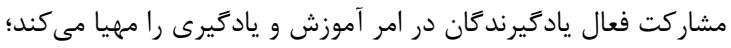

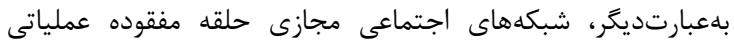

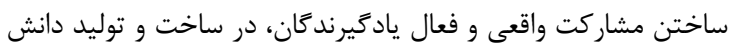

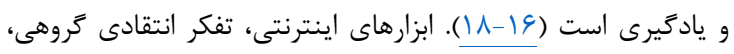

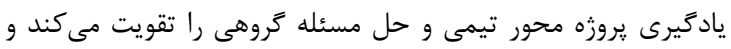

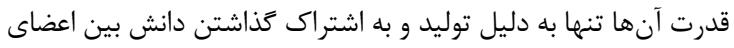

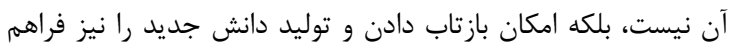

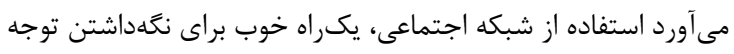

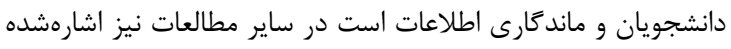

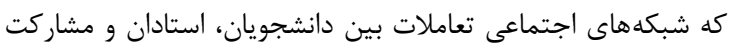

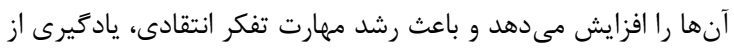

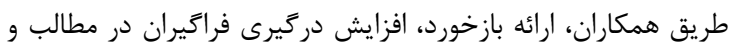

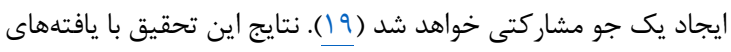

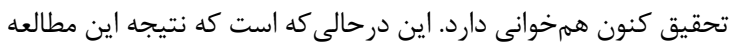

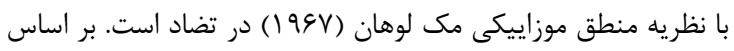

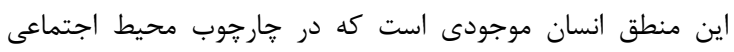

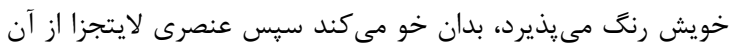

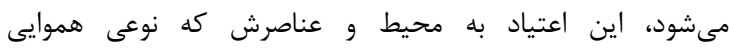

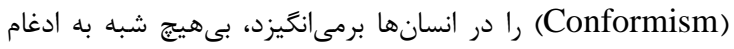

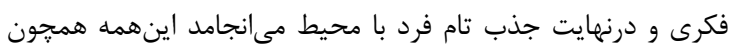

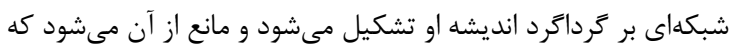

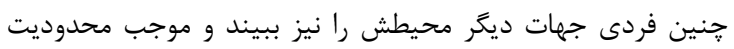

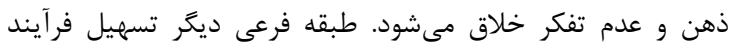

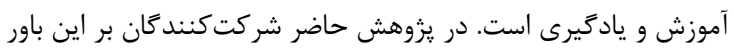

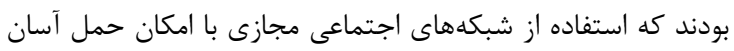

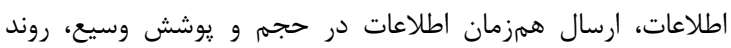

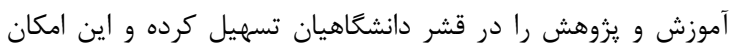

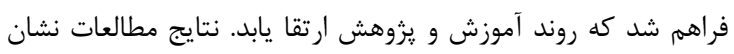

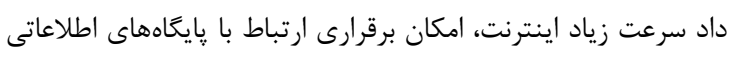

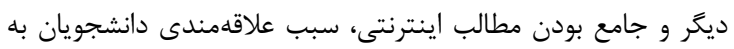

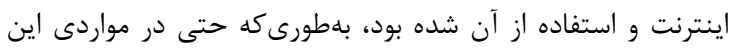

شماره V، يك هيئت علمى با ال سال سابقه تدريس در رشته بهداشت

عمومى).

r-r يادَيرى فردگرايانه

اين طبقه حاصل تحليل كامل مصاحبهها بود و مشاركتكنندگان

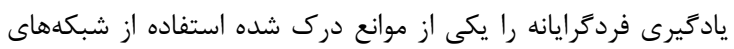

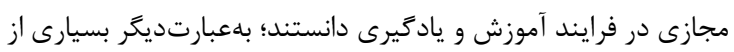

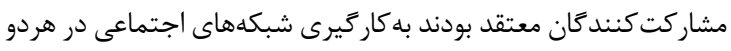

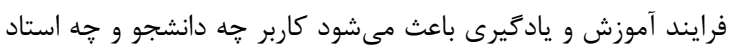

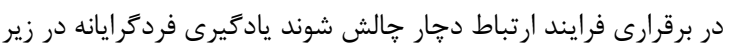

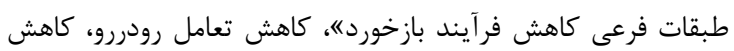

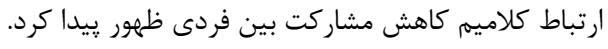

\section{r-r-r كاهش تعامل رو در رو}

بر اساس تحليل مصاحبهها، نشان داده شد كه شبكههاى اجتماعى

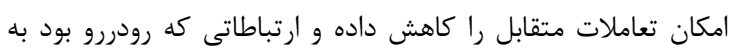

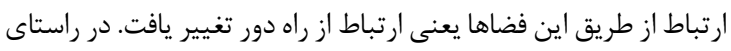

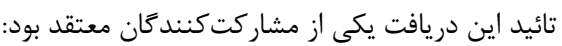

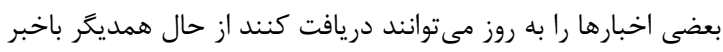

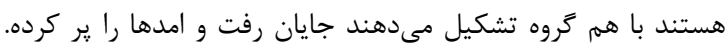

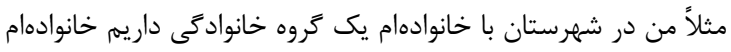

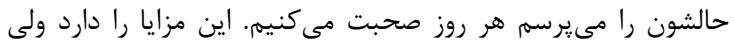

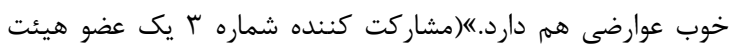

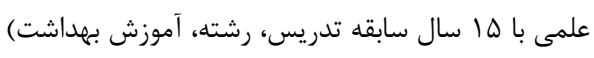

\section{r-r-r}

اين درونمايه نشاندهنده اين است كه فضاهاى مجازى با فراهم كردن

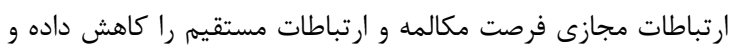

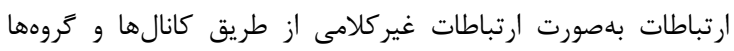

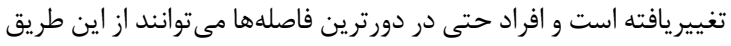

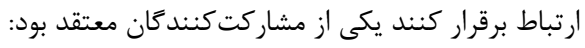

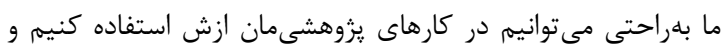

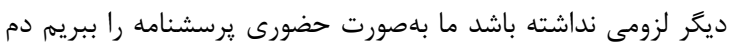

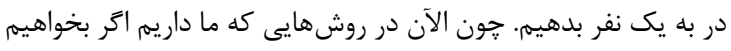

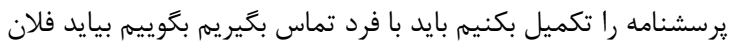

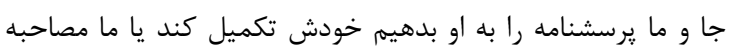

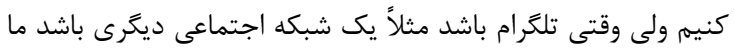

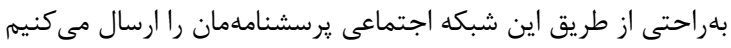

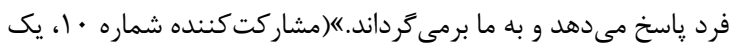

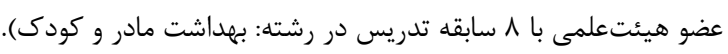

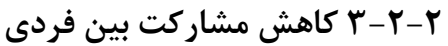

يكى ديكر از درونمايهها كه از طريق تحليل مصاحبهها از ديدكاه

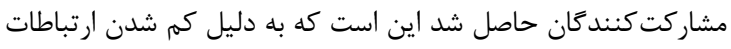

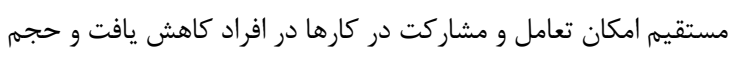

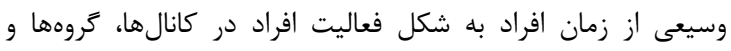

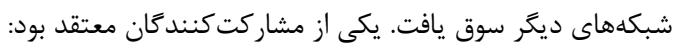

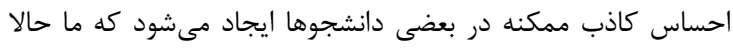

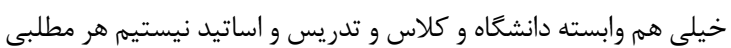


غرقشدكى در اطلاعات، كمبود وقت، بلهروز نبودن استادان، فقدان

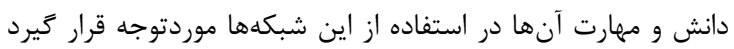

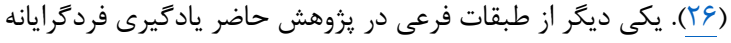

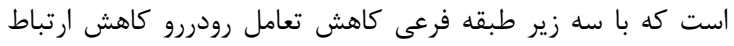

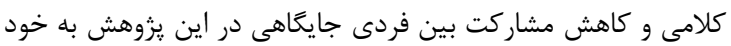

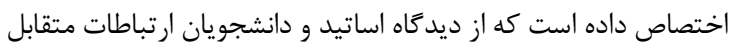

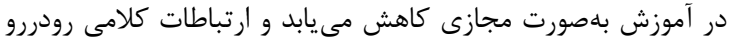

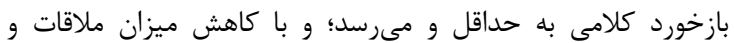

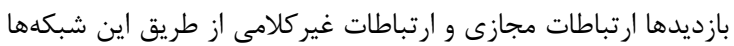

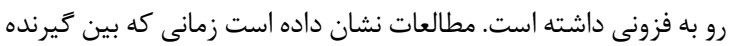

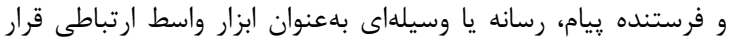

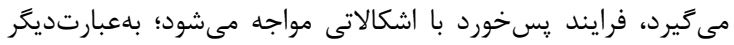

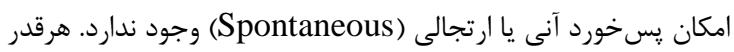

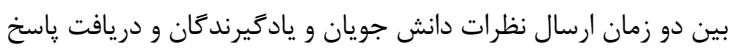

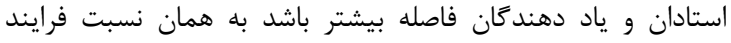

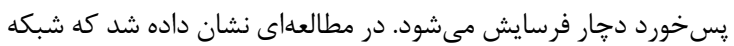

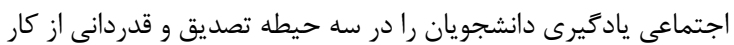

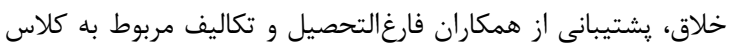

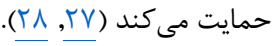

\section{نتيجه تيرى}

بلهور كلى، بهكاركيرى شبكههاى اجتماعى و فضاى مجازى در فرايند

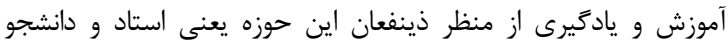

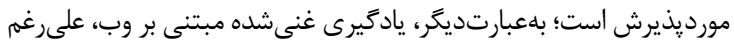

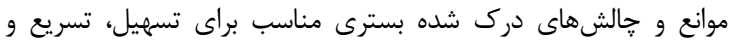

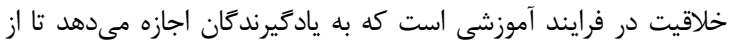

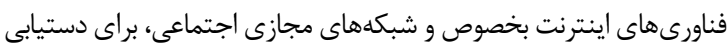

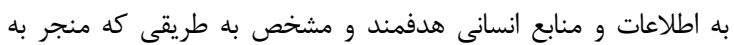

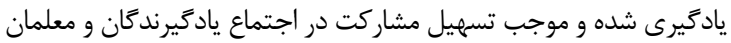

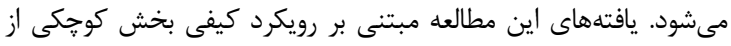

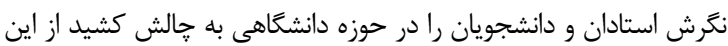

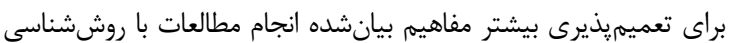

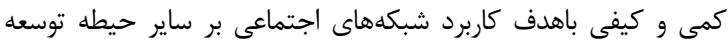

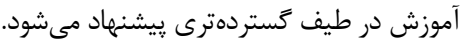

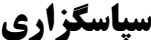

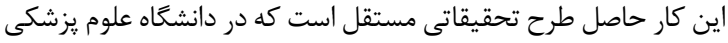

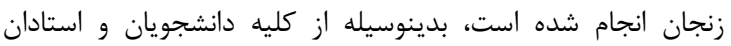

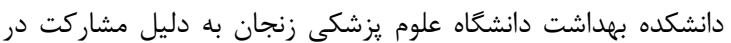
تحقيق قدرانى مى كنيه.

\section{References}

1. McBride K. Social-networking sites in foreign language classes: Opportunities for re-creation. The next generation: Social networking and online collaboration in foreign language learning. 2009;8:3558 .
استفاده بهصورت عادت در آمده بود (• (T). سهولت كار با اين شبكهها و

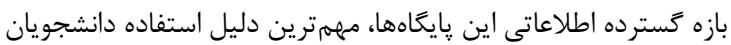

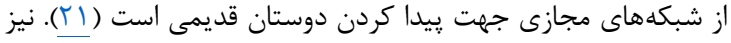

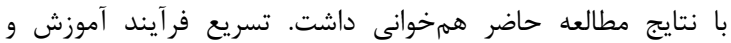

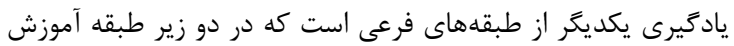

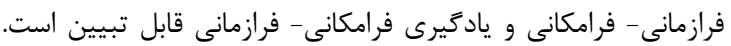

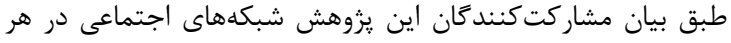

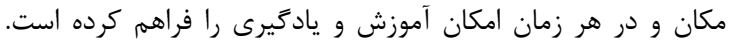

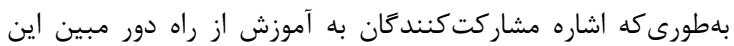

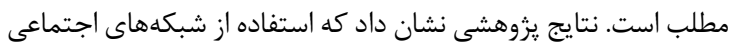

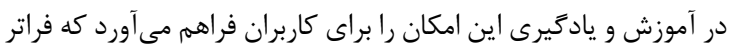

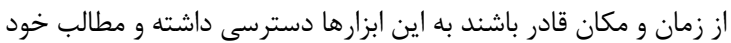

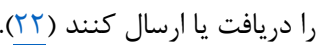

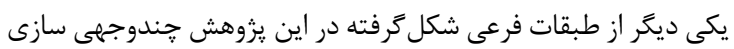

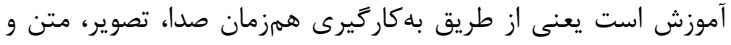

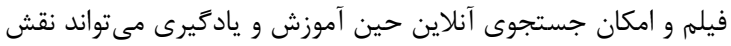

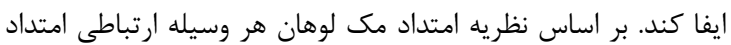

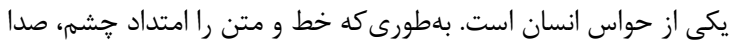

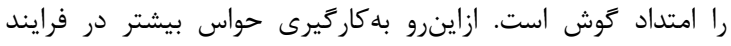

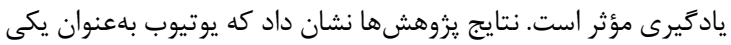

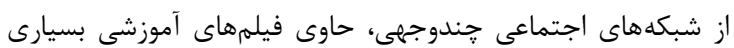

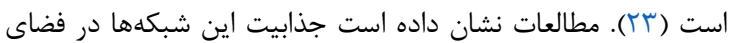

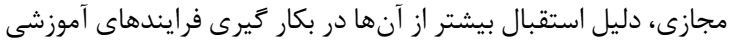

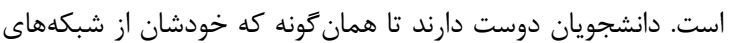

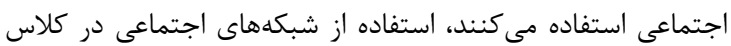

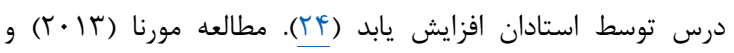

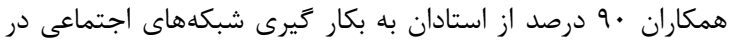

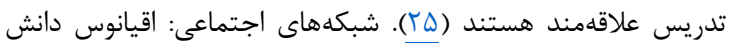

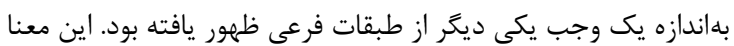

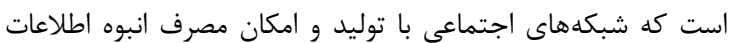

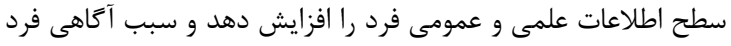

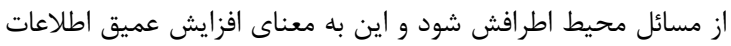

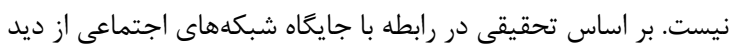

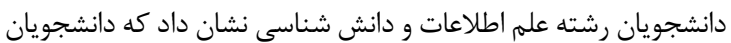

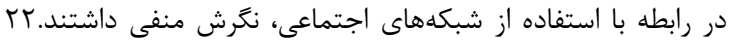

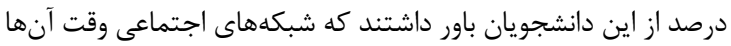

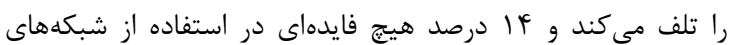

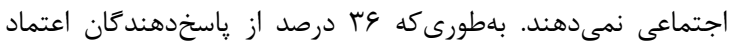

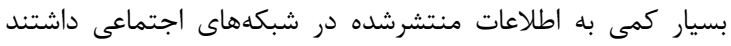

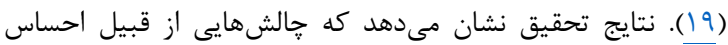

2. Soleimani Pour R. Social networks, opportunities and threats. Rahavard Noor. 2012;14:9-31.

3. Kirschner PA, Karpinski AC. Facebook® and academic performance. Comp Hum Behav. 2010;26(6):1237-45. DOI: 10.1016/j.chb.2010.03.024 
4. Oinas-Kukkonen H, Lyytinen K, Yoo Y. Social networks and information systems: ongoing and future research streams. J Assoc Inf Syst. 2010;11(2):3.

5. Abbasi Shavazi M, Homayoon P. Social media and social relationship: A study of relationship between new communication technologies and social isolation. J Cult Stud Commun. 2014;10(36):43-66.

6. Tower M, Latimer S, Hewitt J. Social networking as a learning tool: nursing students' perception of efficacy. Nurse Educ Today. 2014;34(6):1012-7. DOI: 10.1016/j.nedt.2013.11.006 PMID: 24314881

7. Zaidieh AJY. The use of social networking in education: Challenges and opportunities. World Comp Sci Inf Technol J. 2012;2(1):18-21.

8. Rezvani A. The relationship between the use of virtual social networks and trust in interpersonal relations and academic achievement of students in Birjand. J Med Educ Zanjan. 2017;9(24):33-43.

9. Aryani E, Zahed BA, Moenikia M, Khaleghkhah A. The role of virtual social networks in the research capabilities of postgraduate students. Interdic J Virual Learn Med Sci. 2015;6(2):26-39.

10. Snyder SL, Burke S. Using YouTube in the classroom: a how-to guide. Int J Instruct Technol Distance Learn. 2008;5(4):45-52

11. Mahdavinasab Y. Blog impact on cooperative learning students in the Faculty of Psychology and Educational Sciences. Tehran: Allameh Tabatabaei University; 2012.

12. Roblyer MD, McDaniel M, Webb M, Herman J, Witty JV. Findings on Facebook in higher education: A comparison of college faculty and student uses and perceptions of social networking sites. Internet High Educ. 2010;13(3):134-40. DOI: 10.1016/j.iheduc.2010.03.002

13. Junco R, Cole-Avent GA. An introduction to technologies commonly used by college students. New Dir Stud Serv. 2008;2(124):3-17. DOI: 10.1002/ss.292

14. Veletsianos G, Navarrete C. Online social networks as formal learning environments: Learner experiences and activities. Int Rev Res Open Distributed Learn. 2012;13(1):144. DOI: 10.19173/irrodl.v13i1.1078

15. Imhof M, Vollmeyer R, Beierlein C. Computer use and the gender gap: The issue of access, use, motivation, and performance. Comp Hum Behav. 2007;23(6):2823-37. DOI: 10.1016/j.chb.2006.05.007
16. Fischer F, Mandl H. Knowledge convergence in computer-supported collaborative learning: The role of external representation tools. J Learn Sci. 2005;14(3):405-41.

17. Mason R, Rennie F. Using Web 2.0 for learning in the community. Internet High Educ. 2007;10(3):196-203. DOI: $10.1016 /$ j.iheduc. 2007.06.003

18. Valkenburg PM, Schouten AP, Peter J. Adolescents' identity experiments on the internet. New Media Soc. 2016;7(3):383-402. 10.1177/1461444805052282

19. Beigzadeh A, Kohan S, Yamani N, Rezaei H. Perception of Graduate Students Regarding the Use of Social Networks in Education. Strides Dev Med Educ J Med Educ Dev Cent. 2016;13(3):220-34.

20. Aliramezani H, Borhani F, Okhovati M. Experiences of nursing students in terms of internet information literacy training: a qualitative research. J Qual Res Health Sci. 2015;4(1):22-34.

21. Pempek TA, Yermolayeva YA, Calvert SL. College students' social networking experiences on Facebook. J Appl Dev Psychol. 2009;30(3):227-38. DOI: 10.1016/j.appdev.2008.12.010

22. Redecker C, Ala-Mutka K, Punie Y. Learning 2.0-The impact of social media on learning in Europe. Policy brief. JRC Scientific and Technical Report. 2010 Contract No.: EUR JRC56958 EN.

23. Duncan I, Yarwood-Ross L, Haigh C. YouTube as a source of clinical skills education. Nurse Educ Today. 2013;33(12):1576-80

DOI: 10.1016/j.nedt.2012.12.013 PMID: 23332710

24. Smith N, Kitchenham N, Bowden-Jones H. Pathological gambling and the treatment of psychosis with aripiprazole: case reports. $\mathrm{Br} \mathrm{J}$ Psychiatry. 2011;199(2):158-9. DOI: 10.1192/bjp.bp.110.084996 PMID: 21804151

25. Moran M, Seaman J, Tinti-Kane H. Teaching, Learning, and Sharing: How Today's Higher Education Faculty Use Social Media: Babson Survey Research Group; 2011.

26. Jones N, Blackey H, Fitzgibbon K, Chew E. Get out of MySpace! Comp Educ. 2010;54(3):776-82.

27. Greenhow C. Social Network Sites as Social Learning Resources. 2011.

28. Zarei Zavaraki E, Ghorbani H. The impact of social networks, virtual learning English students. Technol Teach Learn. 2015;1(3):23-36. 